\title{
Sex steroid receptors profiling is influenced by nandrolone decanoate in the ampulla of the fallopian tube: Post-treatment and post-recovery analyses
}

\author{
G.H.B. Andrade ${ }^{\text {a }}$, V.A. Simão ${ }^{a}$, B.R. Souza ${ }^{a}$, L.G.A. Chuffa ${ }^{b}$, I.C.C. Camargo ${ }^{a, *}$ \\ a São Paulo State University - UNESP, School of Sciences, Humanities and Languages, Department of Biotechnology, Assis, SP, Brazil \\ ${ }^{\mathrm{b}}$ São Paulo State University - UNESP, Institute of Biosciences, Department of Anatomy, Botucatu, SP, Brazil
}

\section{A R T I C L E I N F O}

\section{Keywords:}

Nandrolone decanoate

Fallopian tube

Sex steroids receptors

\begin{abstract}
A B S T R A C T
Anabolic androgenic steroids (AAS) are recommended for therapeutic clinic, but their use has increased in recent decades for aesthetic reasons. No study has evaluated the impact of AAS in the fallopian tube, after treatment and recovery periods. Herein, the aim of study was to investigate the effects of Nandrolone Decanoate (ND), administered in different doses $(1.87 ; 3.75 ; 7.5$ and $15 \mathrm{mg} / \mathrm{kg}$ ) on the ampulla of the fallopian tube in rats, following post-treatment (PT; 15 consecutive days) and post-recovery (PR; 30 consecutive days) periods. The control group received mineral oil. Estrous cycle was monitored daily during both periods and in sequence the rats ( $n=8$ /group/period) were killed. All ND-treated animals showed estral acyclicity during the PT and PR periods, but the histomorphometric changes in the fallopian tube varied according to the ND dose level. The expression of AR, ER $\alpha$ and ER $\beta$ varied in the nucleus and cytoplasm of epithelial cells. No AR expression was observed in the stroma. The muscle cells exhibited variation in immunostaining. In conclusion, ND promoted histomorphometric and immunohistochemical changes in the ampullary portion of the fallopian tube after treatment and recovery periods in a dose-independent manner.
\end{abstract}

\section{Introduction}

AAS are synthetic substances chemically related to testosterone (Rocha et al., 2014; Frizon et al., 2005), which present anabolic and androgenic activities, respectively correlated to stimulation of growth and maturation of non-reproductive tissues and maintenance of secondary sexual characteristics and reproductive function (Berne and Levy, 2000). Nandrolone decanoate (ND) is considered one of the most used synthetic steroids worldwide (Abrahin et al., 2013; Iriart et al., 2009), with moderate androgenic effects and strong anabolic properties (Kicman, 2008).

Regarding the therapeutic applications, AAS are recommended for the treatment of chronic diseases associated with the catabolic state of patient such as acquired immunodeficiency syndrome (AIDS), chronic obstructive pulmonary disease, cancer, severe burns, hepatic or renal failure and post-surgical recovery (Kicman, 2008; Shahidi, 2001). They are also prescribed for postmenopausal hormone replacement therapy (HRT) and in cases of age-related sarcopenia (Arlt, 2006; Evans, 2004). However, the non-therapeutic use of AAS increased in recent decades among men and women, exclusively for aesthetic reasons. In women, its indiscriminate use promotes various side effects that are dose and period-dependent (Bonetti et al., 2008; Kam and Yarrow, 2005) and include breast atrophy, body hair growth, voice deepening, oligoamenorrhea, clitoris hypertrophy, anovulation and aggressiveness (Hoffman and Ratamess, 2006; Maravelias et al., 2005; Cannavo et al., 2001).

The adverse effects of ND on estrous cycle and ovarian/uterine architecture are well-described and reported to be associated with estrous cycle interruption (Chuffa et al., 2011; Bento-Silva et al., 2010; Gerez et al., 2005; Blasberg et al., 1998), suppression of the reproductive capacity (Belardin et al., 2014; Camargo et al., 2009) and long-lasting histopathological changes in the ovaries and uterus (Simão et al., 2015; Simão et al., 2016; Belardin et al., 2014; Camargo et al., 2014; Mobini Far et al., 2007). These effects can occur even after use of low doses and are mostly time-dependent (Simão et al., 2015; Belardin et al., 2014).

To date, the effect of AAS on the morphophysiology of the fallopian tube is still poorly explored. Because the fallopian tube plays important roles on bidirectional transport of gametes, as well as in nourishment and transport of the developing embryo towards the uterus at a precisely timed movement (Akison et al., 2014), an unexpected hormonal imbalance could affect its natural physiology resulting in low fertility rates.

\footnotetext{
* Corresponding author at: Department of Biotechnology, School of Sciences, Humanities and Language, São Paulo State University - UNESP, Dom Antonio Avenue, 2100, Zip code: 19806-170, Assis, SP, Brazil.

E-mail address: camargo@assis.unesp.br (I.C.C. Camargo).
} 
During the reproductive cycle, the mucosa of the fallopian tube undergoes morphological changes (Bylander, 2014; Patek et al., 1972), regulated by a set of sex steroid hormones (Akison et al., 2014; Goldberg and Friedman, 1995). After estradiol $\left(E_{2}\right)$ and progesterone $\left(\mathrm{P}_{4}\right)$ bind to its receptors ER or PR expressed on the fallopian tube epithelium, a number of molecular and structural functions take place (Lyons et al., 2006; Mahmood et al., 1998). While $\mathrm{E}_{2}$ stimulates epithelial cell hypertrophy, mucosa secretion and ciliogenesis (Donnez et al., 1985), $\mathrm{P}_{4}$ regulates ciliary beating frequency (Bylander et al., 2013). Previous study showed that the administration of ethinylestradiol to fertile and postmenopausal women cause no ciliary alteration, whereas treatment with testosterone enanthate lead to decrease in the number of ciliated cells of the fimbrial and ampullary regions (Patek et al., 1973).

Despite extensive studies are conducted to evaluate the effects of AAS in the reproduction, no study has focused on the effects of ND regarding the morphology and expression of sex steroid receptors in the fallopian tube. Therefore, this study aimed to evaluate the effects of different doses of ND on the ampulla of the fallopian tube especially involving the expression of androgen receptor (AR), and estrogen receptors (ER $\alpha$ and ER $\beta$ subunits) after treatment and recovery periods.

\section{Materials and methods}

\subsection{Animals}

Eighty Wistar female rats (Rattus norvegicus), 70-day-old, and approximately $250 \mathrm{~g}$ body weight, were housed in the Central Biotherium of School of Sciences, Humanities and Languages (UNESP, Assis, São Paulo, Brazil). All animals were individually kept in polypropylene cages with laboratory-grade pine shavings as bedding and maintained in a room with controlled temperature and luminosity $\left(22 \pm 2^{\circ} \mathrm{C}\right.$; 12 h-light/12 h-dark, respectively). Rat chow (Nuvital, Colombo, Paraná, Brazil) and tap water were provided ad libitum. Experimental protocol followed the ethical principles in animal research adopted by the Brazilian College of Animal and was previously approved by the Ethics Committee for Animals Use (Permit Number 005/2011).

\subsection{Drug}

Nandrolone decanoate (17ß-hydroxi-19-nor-4-androsterone-3-one), also known as Deca Durabolin ${ }^{\mathrm{Tm}}$, was purchased from Schering-Plough Laboratory (São Paulo, Brazil). It is commercially available as an injectable oily solution, containing $50 \mathrm{mg}$ of the androgen.

\subsection{Experimental design}

Rats with regular estrous cycle were weighed and randomly divided into five groups ( $n=16 /$ group): control, treated with $0.1 \mathrm{~mL}$ of mineral oil, and ND-treated groups that received different doses (1.87, $3.75,7.5$ and $15 \mathrm{mg} / \mathrm{kg}$ b.w.). The injections were administered subcutaneously, once daily, for 15 consecutive days, at the same time (12:30-13:00 a.m). The doses were chosen based on our previous reports (Simão et al., 2015; Simão et al., 2016; Belardin et al., 2014). Briefly, the highest doses of ND $(7.5$ and $15 \mathrm{mg} / \mathrm{kg})$ are usually employed in animal studies or used without therapeutic recommendation by young and adults. The lowest doses $(1.87$ and $3.75 \mathrm{mg} / \mathrm{kg}$ ) are clinically recommended for various clinical treatments. Allometric calculations for animal dosing were performed as described by Belardin et al. (2014).

At the end of 15 days of experimental treatment, eight animals from each group were anesthetized and killed, corresponding to the posttreatment period (PT) of the study (Fig. 1A). Following the treatment period, the remaining rats from each group ( $n=8$ /group), were kept without any treatment for a period of 30 days and killed at the end of this period, corresponding to the post-recovery period (PR) of the study

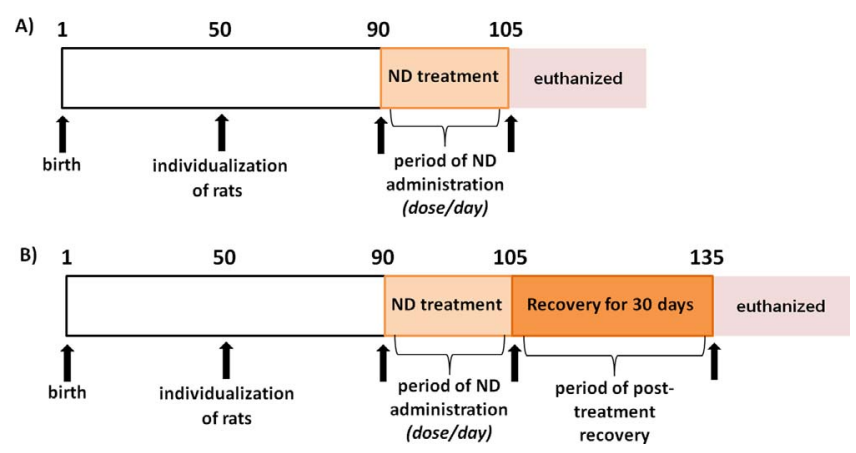

Fig. 1. Chronological experimental design in days. (A) At 90-days-old, eight rats per dose level $(1.87,3.75,7.5$ and $15 \mathrm{mg} \mathrm{ND} / \mathrm{kg}$ ) were killed at the end of the treatment period. (B) Eight rats per dose level (1.87, 3.75, 7.5 and $15 \mathrm{mg} \mathrm{ND} / \mathrm{kg}$ ) received the treatment for 15 days and were maintained in the recovery period for 30 days (105-135-days-old), followed by killing.

(Fig. 1B).

\subsection{Assessment of estrous cycle}

During the treatment and recovery periods (15 and 30 consecutive days, respectively), the estrous cycle was monitored daily by cytological examination (vaginal swabs). The time of collection was fixed at 9:00 a.m. The phases of cycle were identified under a light microscope (Olympys CX31 RBSFA, Tokyo, Japan), according to the criteria described by Goldman et al. (2007).

\subsection{Histomorphometric and immunohistochemical analysis}

At the end of each period (PT and PR), the animals from each group were killed using anaesthetic saturation in $\mathrm{CO}_{2}$, followed by decapitation (Simão et al., 2016).

The right oviduct was collected and fixed in buffered $10 \%(\mathrm{v} / \mathrm{v})$ formalin $\left(0.2 \mathrm{M} \mathrm{NaH} \mathrm{NO}_{4}, \quad 0.2 \mathrm{M} \mathrm{Na} \mathrm{Na}_{2} \mathrm{HPO}_{4}, 37 \%\right.$ formaldehyde LABYMPEX Ltda., Diadema, São Paulo, Brazil) for $24 \mathrm{~h}$. Subsequently, the oviduct was dehydrated in ethyl alcohol, clarified in xylene, and embedded in paraffin (Oxford Labware, St. Louis, MO, USA). The blocks were cut into $4-\mu \mathrm{m}$ thick sections using a microtome Leica RM2125 (Germany), and tissue sections were stained with hematoxylin-eosin ( $\mathrm{H}$ \&E) and Mallory's Trichromic.

For immunohistochemistry analysis, samples of the left oviduct were deparaffinized in xylene and hydrated in ethanol solutions. Antigen retrieval was performed in a microwave oven at $700-800 \mathrm{~W}$ for $15 \mathrm{~min}(3 \times 5 \mathrm{~min})$ in sodium citrate buffer $0.01 \mathrm{M}$, pH 6.0. After blocking peroxidase activity, the tissues were incubated with $3 \%$ bovine serum albumin (BSA) for $1 \mathrm{~h}$ to prevent nonspecific binding. The tissue sections were then incubated in a humidified chamber overnight at $4{ }^{\circ} \mathrm{C}$ with primary antibody anti-AR (dilution 1:100, NB300-551, Novus Biologicals, Littleton, CO, USA), anti-estrogen receptor alpha (ER $\alpha$; 1:100 dilution, NB110-56961, Novus Biologicals) and anti-estrogen receptor beta (ERß; dilution $1 \mu \mathrm{g} / \mathrm{mL} \mathrm{NB120-3577,} \mathrm{Novus} \mathrm{Biologicals).}$ After reacting with the primary antibodies, the slides were washed in phosphate buffered saline ( $\mathrm{pH} 7.0$ ), and rapidly incubated with the secondary antibody (Anti-Mouse Polymer IgG or Anti-Rabbit - DAKO CYT) at room temperature for $1 \mathrm{~h}$. After incubation, the slides were placed to react with the chromogen diaminobenzidine (Sigma, St. Louis, MO, USA) for $5 \mathrm{~min}$. Finally, the sections were washed in deionized water, counterstained with Harris hematoxylin. Negative controls were used by omitting the primary antibody.

The criteria for the immunohistochemistry analysis were based on the following staining intensity levels: absent $(-)$, low $(+)$, moderate $(++)$ and strong $(+++)$. In cases in which the intensity of staining differed between the nucleus and the cytoplasm, the symbol (N) or (C) was used in superscript, respectively. When necessary, a vertical bar (/) 

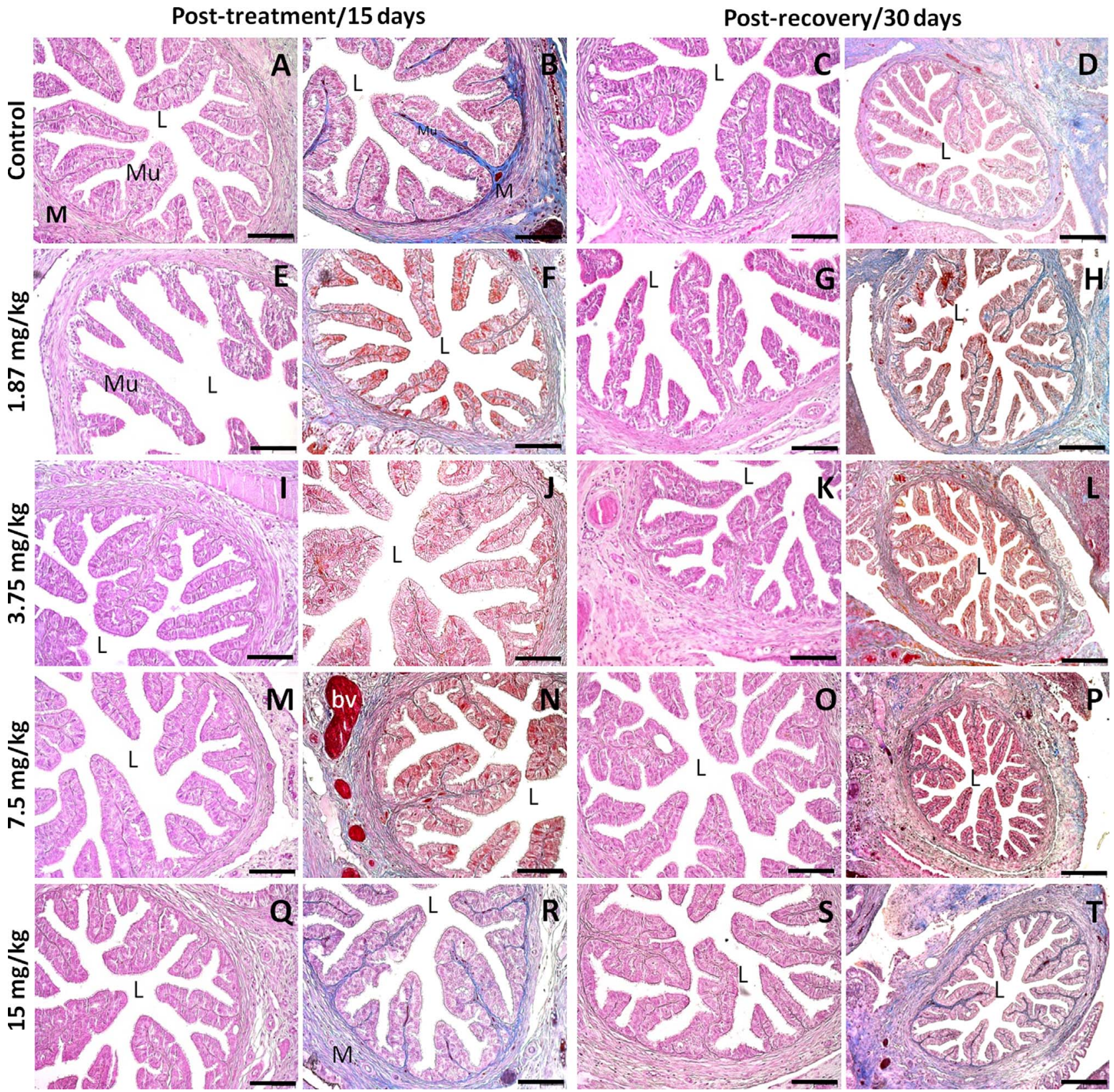

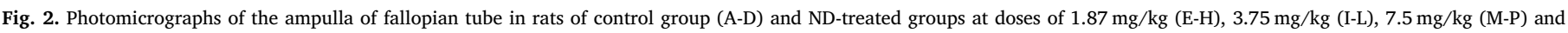

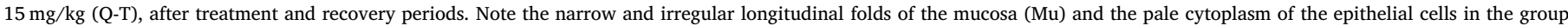

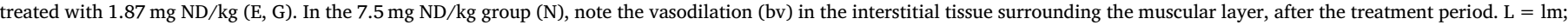

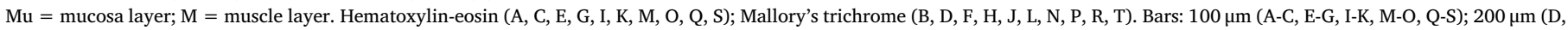
H, L, P, T).

was used to indicate the variation in cell immunostaining regarding different animals in the same group.

For morphometric analysis, five sections/animal/group in each period (PT and PR) were stained with hematoxylin-eosin, being randomly chosen to measure the luminal area, height of the ciliated and secretory cells, thickness of the muscle layer and area of the blood vessels surrounding the muscle layer $(10 \times$ magnification). The height of the ciliated and secretory cells was measured from the basement membrane to the apical membrane, excluding the cilia. To measure the thickness of the muscular layer, the outer longitudinal and inner circular layers were considered.

All analyses were performed in blinded test using a Zeiss Scope A1Axio microscope connected to an AxioCam ICc3 camera, and the digitalized images were performed using an image analyzer Axio Vision software, version 4.7.2.

\subsection{Statistical analysis}

For morphometric data, non-parametric Kruskal-Wallis analysis complemented by Dunn test was used, and the results were expressed as median \pm interquartile deviation. Statistical analysis was performed using GraphPad Prism software, version 5.0 (GraphPad Software Inc., San Diego, California, USA). Statistical significance was set at $\mathrm{P}<0.05$.

\section{Results}

Regardless of ND dose, all animals presented interruption of estrous 
Table 1

Histomorphometric parameters in the ampulla of the fallopian tube, after treatment and recovery periods.

\begin{tabular}{|c|c|c|c|c|c|}
\hline \multirow[t]{3}{*}{ Parameters } & \multicolumn{5}{|c|}{ Experimental groups ( $n=8 /$ group/period) } \\
\hline & \multicolumn{5}{|c|}{ Post-treatment period/15 days } \\
\hline & Control & $1.87 \mathrm{mg} \mathrm{ND} / \mathrm{kg}$ & $3.75 \mathrm{mg} \mathrm{ND} / \mathrm{kg}$ & $7.5 \mathrm{mg} \mathrm{ND} / \mathrm{kg}$ & $15 \mathrm{mg} \mathrm{ND} / \mathrm{kg}$ \\
\hline Luminal area $\left(\mathrm{mm}^{2}\right)$ & $0.05 \pm 0.03 \mathrm{a}$ & $0.16 \pm 0.04 \mathrm{~b}$ & $0.10 \pm 0.01 \mathrm{ab}$ & $0.10 \pm 0.01 \mathrm{ab}$ & $0.07 \pm 0.003 \mathrm{a}$ \\
\hline Blood vessels area $\left(\mu \mathrm{m}^{2}\right)$ & $140.2 \pm 23.7 \mathrm{a}$ & $207.5 \pm 63.7 \mathrm{ad}$ & $566.9 \pm 132.5$ bd & $1262 \pm 1597 b$ & $438.3 \pm 156.9 \mathrm{~d}$ \\
\hline Muscle layer thickness $(\mu \mathrm{m})$ & $46.3 \pm 6.3 \mathrm{ac}$ & $34.0 \pm 6.0 \mathrm{~b}$ & $42.5 \pm 5.6 \mathrm{ac}$ & $38.3 \pm 9.3 \mathrm{ab}$ & $50.9 \pm 6.1 \mathrm{c}$ \\
\hline Ciliated cells height $(\mu \mathrm{m})$ & $18.2 \pm 1.3 \mathrm{ac}$ & $14.5 \pm 1.5 \mathrm{~b}$ & $17.8 \pm 1.3 \mathrm{a}$ & $19.3 \pm 1.5 \mathrm{a}$ & $16.7 \pm 0.9 \mathrm{c}$ \\
\hline Secretory cells height $(\mu \mathrm{m})$ & $11.4 \pm 1.1 \mathrm{ab}$ & $12.5 \pm 1.5 \mathrm{a}$ & $10.9 \pm 1.1 \mathrm{~b}$ & $11.8 \pm 2.0 \mathrm{ab}$ & $12.3 \pm 1.7 \mathrm{ab}$ \\
\hline
\end{tabular}

Parameters

Experimental groups $(\mathrm{n}=8 /$ group/period)

\begin{tabular}{|c|c|c|c|c|c|}
\hline & \multicolumn{5}{|c|}{ Post-recovery period/30 days } \\
\hline & Control & $1.87 \mathrm{mg} \mathrm{ND} / \mathrm{kg}$ & $3.75 \mathrm{mg} \mathrm{ND} / \mathrm{kg}$ & $7.5 \mathrm{mg} \mathrm{ND} / \mathrm{kg}$ & $15 \mathrm{mg} \mathrm{ND} / \mathrm{kg}$ \\
\hline Luminal area $\left(\mathrm{mm}^{2}\right)$ & $0.11 \pm 0.01 \mathrm{a}$ & $0.09 \pm 0.03 \mathrm{a}$ & $0.10 \pm 0.02 \mathrm{a}$ & $0.09 \pm 0.01 \mathrm{a}$ & $0.10 \pm 0.02 \mathrm{a}$ \\
\hline Blood vessels area $\left(\mu \mathrm{m}^{2}\right)$ & $394.3 \pm 106.6 \mathrm{ab}$ & $318.7 \pm 59.3 \mathrm{a}$ & $306.7 \pm 94.2 \mathrm{a}$ & $597.6 \pm 656.2 \mathrm{~b}$ & $887.8 \pm 658.5 b$ \\
\hline Muscle layer thickness $(\mu \mathrm{m})$ & $39.6 \pm 5.5 \mathrm{a}$ & $42.9 \pm 6.5 \mathrm{ab}$ & $45.3 \pm 4.4 \mathrm{ab}$ & $47.0 \pm 9.2 \mathrm{ab}$ & $50.6 \pm 9.3 \mathrm{~b}$ \\
\hline Ciliated cells height $(\mu \mathrm{m})$ & $16.4 \pm 1.2 \mathrm{ab}$ & $14.9 \pm 1.3 \mathrm{a}$ & $17.4 \pm 0.7 \mathrm{bc}$ & $17.7 \pm 1.5 \mathrm{c}$ & $17.4 \pm 0.8 \mathrm{bc}$ \\
\hline Secretory cells height $(\mu \mathrm{m})$ & $9.9 \pm 2.2 \mathrm{a}$ & $11.8 \pm 1.4 \mathrm{a}$ & $11.1 \pm 0.9 \mathrm{a}$ & $11.9 \pm 1.5 \mathrm{a}$ & $12.1 \pm 1.4 \mathrm{a}$ \\
\hline
\end{tabular}

Data are expressed as the median \pm interquartile deviation. In the same line, values followed by different letters indicate statistical differences among the groups $(\mathrm{P}<0.05)$.

cycle in the first days of treatment, which exhibited persistent diestrus until the 30-day recovery period. Then, all animals of ND-treated and control groups were killed in the diestrus phase of the estrous cycle. Considering the variation of the estrous cycle between the females, animals from the control group were killed in the first diestrus after the end of each period, with an average difference of 2 days compared to the females of the ND-treated groups.

Histologically, all experimental groups presented a well-differentiated mucosa, muscular and serous layers (Fig. 2), both in the PT and PR periods. The mucosa layer of the ampulla exhibited numerous longitudinal folds, in which they send projections into the lumen (Fig. 2).

In the group treated with $1.87 \mathrm{mg} \mathrm{ND} / \mathrm{kg}$ (Fig. 2E-H), the folds showed irregular aspect creating a large space between them, which resulted in a significant increase $(\mathrm{p}<0.05)$ in the luminal area after the PT period, compared to the control and treated with a dose of $15 \mathrm{mg}$ $\mathrm{ND} / \mathrm{kg}$ groups (Table 1). In the PR period, the luminal area of the ampulla portion was similar in all experimental groups (Table 1).

The mucosal epithelial lining was simple columnar in the control and ND-treated groups (Fig. 2), and presented two basic types of cells, ciliated and secretory (Fig. 5A), being the ciliated cells the most representative. Sometimes the epithelium displayed cellular hyperplasia in all groups (Fig. 5B-D). The group treated with the lowest dose $(1.87 \mathrm{mg} \mathrm{ND} / \mathrm{kg}$ ) exhibited ciliated cells with pale cytoplasm in the basal surface, after the treatment (Fig. 2E) and recovery (Fig. 2G) periods. Furthermore, in this group there was a significant decrease in the height of ciliated cells, compared to the control group and other NDtreated groups, in the PT period (Table 1). However, in the PR period, the height of the ciliated cells in the group receiving the lowest dose was similar $(p>0.05)$ to the control group, but it remained significantly reduced in comparison to the other androgenized groups (Table 1). At the higher dose of the steroid ( $15 \mathrm{mg} \mathrm{ND} / \mathrm{kg}$ ), it was observed that the height of the ciliated cells was significantly lower than the intermediate doses ( 3.75 and $7.5 \mathrm{mg} \mathrm{ND} / \mathrm{kg}$ ), but similar to the control group, when the PT period was evaluated. In the PR period, the groups that received doses of $3.75,7.5$ and $15 \mathrm{mg} \mathrm{ND} / \mathrm{kg}$ presented the same height of the ciliated cells. Considering the secretory cells of the luminal lining, all androgenized groups presented cellular height similar to the control group after the treatment and recovery periods (Table 1).

The thin lamina propria of the mucosa layer, constituted by connective tissue, presented collagen fibrils in all experimental groups, after the treatment (Fig. 2B, F, J, N and R) and recovery (Fig. 2D, H, L, P and $\mathrm{T}$ ) periods.

The thickness of the muscular layer was significantly reduced $(\mathrm{p}<0.05)$ in the group receiving the lowest dose of $\mathrm{ND}(1.87 \mathrm{mg} / \mathrm{kg})$, compared to the control group and androgenized groups treated with 3.75 and $15 \mathrm{mg} \mathrm{ND} / \mathrm{kg}$, after the PT period (Table 1). In the PR period, only the group treated with the dose of $15 \mathrm{mg} \mathrm{ND} / \mathrm{kg}$ showed increased ( $\mathrm{p}<0.05$ ) muscle layer thickness, but did not differ from the other androgenized groups (Table 1).

There was a significant increase in area of blood vessels located around the outer longitudinal muscle layer in groups receiving doses of 3.75, 7.5 and $15 \mathrm{mg} \mathrm{ND} / \mathrm{kg}$, compared to the control group, in the PT period (Table 1; Fig. 2N). In the comparison between the different dosages of ND, the largest area of the vessels was observed after treatment with a dose of $7.5 \mathrm{mg} / \mathrm{kg}$, which differed significantly from the doses of 1.87 and $15 \mathrm{mg} / \mathrm{kg}$. After a recovery period (Table 1), the vascular area of all ND-treated groups was similar to the control group. However, the animals that received the highest dose levels (7.5 and $15 \mathrm{mg} \mathrm{ND} / \mathrm{kg}$ ) showed larger blood vessels area than those receiving the lowest doses (1.87 and $3.75 \mathrm{mg} \mathrm{ND} / \mathrm{kg}$ ).

Immunohistochemical data of sex steroid receptors regarding the epithelium, stroma and muscle layer of ampulla portion of the fallopian tube in all experimental groups, in the PT and PR periods, are presented in Table 2 and Figs. 3 and 4. In PT period, the immunostaining for steroid receptors in ciliated and secretory cells of luminal epithelium is highlighted in Fig. 5B-D.

The ampulla epithelium presented moderate nuclear AR expression in animals of control and ND-treated groups in the PT period (Table 2). In the control group, cytoplasmic staining of AR was moderate and in the androgenized groups this expression ranged from moderate to strong in the epithelial cells (Table 2; Fig. 3A, C, E, G and I; Fig. 5B). Considering the PR period (Table 2), there was strong immunostaining for the nuclear AR in the ciliated and secretory cells of the animals receiving the lowest ND dose (Fig. 3D), while at the highest dose was observed a strong immunostaining for cytoplasmic AR (Fig. 3J). For both periods (PT and PR), the AR expression was absent in the stromal cells in all experimental groups (Fig. 3A-J). In muscle layer, the AR expression was low for the control group, but ranged from low to moderate in ND-treated groups after the PT and PR periods (Table 2).

In the PT period, the ER $\alpha$ expression was stronger in the cytoplasm 
Table 2

Immunostaining of sex steroid receptors in the ampulla of the fallopian tube in the different experimental groups, after treatment and recovery periods.

\begin{tabular}{|c|c|c|c|c|c|}
\hline \multirow[t]{2}{*}{ Parameters } & \multicolumn{5}{|c|}{ Experimental groups ( $n=8 /$ group/period) } \\
\hline & Control & $\begin{array}{l}1.87 \mathrm{mg} \\
\mathrm{ND} / \mathrm{kg}\end{array}$ & $\begin{array}{l}3.75 \mathrm{mg} \\
\mathrm{ND} / \mathrm{kg}\end{array}$ & $\begin{array}{l}7.5 \mathrm{mg} \\
\mathrm{ND} / \mathrm{kg}\end{array}$ & $\begin{array}{l}15 \mathrm{mg} \\
\mathrm{ND} / \mathrm{kg}\end{array}$ \\
\hline \multicolumn{6}{|l|}{$\begin{array}{l}\text { Post-treatment } \\
\text { period }\end{array}$} \\
\hline Epithelium & $\begin{array}{c}++{ }^{\mathrm{N}}+ \\
+{ }^{\mathrm{C}}\end{array}$ & $\begin{array}{c}+{ }^{\mathrm{N}}++ \\
+{ }^{\mathrm{C}}\end{array}$ & $\begin{array}{c}++^{\mathrm{N}}+ \\
+/+++^{\mathrm{C}}\end{array}$ & $\begin{array}{c}++^{\mathrm{N}}+ \\
+/++ \\
+^{\mathrm{C}}\end{array}$ & $\begin{array}{c}++^{N}+ \\
++^{C}\end{array}$ \\
\hline Stroma & - & - & - & - & - \\
\hline Muscle layer & + & $+/++$ & $+/++$ & $+/++$ & $+/++$ \\
\hline $\begin{array}{l}\text { ER } \alpha \\
\text { Epithelium }\end{array}$ & $\begin{array}{c}+++^{N} \\
++^{C}\end{array}$ & $\begin{array}{c}+{ }^{\mathrm{N}}++ \\
+\mathrm{C}\end{array}$ & $\begin{array}{c}+/++^{\mathrm{N}} \\
++{ }^{\mathrm{C}}\end{array}$ & $\begin{array}{l}+/++^{\mathrm{N}} \\
+++^{\mathrm{C}}\end{array}$ & $\begin{array}{c}+{ }^{N}++ \\
+{ }^{C}\end{array}$ \\
\hline $\begin{array}{l}\text { Stroma } \\
\text { Muscle layer }\end{array}$ & $\begin{array}{c}+^{\mathrm{N}} \\
+++^{\mathrm{N}} \\
-^{\mathrm{C}}\end{array}$ & $\begin{array}{c}++ \\
+++^{\mathrm{N}} \\
+^{\mathrm{C}}\end{array}$ & $\begin{array}{c}++ \\
+++^{\mathrm{N}} \\
+^{\mathrm{C}}\end{array}$ & $\begin{array}{c}+ \\
++\end{array}$ & $++^{+}+{ }^{\mathrm{C}}$ \\
\hline $\begin{array}{l}\text { ER } \beta \\
\text { Epithelium }\end{array}$ & $\begin{array}{c}-{ }^{N}++ \\
+C\end{array}$ & $\begin{array}{c}-{ }^{N}++ \\
+C\end{array}$ & $\begin{array}{c}-\mathrm{N}_{+}^{+}+ \\
+\mathrm{C}\end{array}$ & $\begin{array}{c}-{ }^{N}++ \\
+{ }^{C}\end{array}$ & $\begin{array}{c}-\mathrm{N}_{+}++ \\
{ }^{\mathrm{C}}\end{array}$ \\
\hline $\begin{array}{l}\text { Stroma } \\
\text { Muscle layer }\end{array}$ & $+^{\mathrm{C}}$ & $+^{\mathrm{C}}$ & $+^{\mathrm{C}}$ & $+^{\mathrm{C}}$ & ${ }_{+}^{-}$ \\
\hline \multicolumn{6}{|l|}{$\begin{array}{c}\text { Post-recovery } \\
\text { period }\end{array}$} \\
\hline Epithelium & $+{ }^{\mathrm{N}}++^{\mathrm{C}}$ & $\begin{array}{c}++{ }^{\mathrm{N}}+ \\
+{ }^{\mathrm{C}}\end{array}$ & $\begin{array}{c}-/+{ }_{+}^{\mathrm{N}}+ \\
+{ }^{\mathrm{C}}\end{array}$ & $\begin{array}{c}+/++^{\mathrm{N}} \\
++^{\mathrm{C}}\end{array}$ & $\begin{array}{c}+^{N}++ \\
+^{C}\end{array}$ \\
\hline Stroma & - & - & - & - & - \\
\hline Muscle layer & + & $+/++$ & + & $+1++$ & $+1++$ \\
\hline \multicolumn{6}{|l|}{$\mathrm{ER} \alpha$} \\
\hline Epithelium & $\begin{array}{c}+++^{\mathrm{N}} \\
++^{\mathrm{C}}\end{array}$ & $\begin{array}{c}+++^{\mathrm{N}} \\
+{ }^{\mathrm{C}}\end{array}$ & $\begin{array}{c}-/+{ }^{\mathrm{N}}+ \\
+{ }^{\mathrm{C}}\end{array}$ & $\begin{array}{c}-/+{ }^{N}+ \\
+{ }^{C}\end{array}$ & $\begin{array}{c}++/+ \\
++^{N}+ \\
++^{C}\end{array}$ \\
\hline Stroma & $+^{\mathrm{N}}$ & $+{ }^{\mathrm{N}}$ & - & $+{ }^{\mathrm{N}}$ & $++{ }^{N}$ \\
\hline Muscle layer & $\begin{array}{c}+++^{\mathrm{N}} \\
{ }_{-}^{\mathrm{C}}\end{array}$ & $\begin{array}{c}+++^{\mathrm{N}} \\
+{ }^{\mathrm{C}}\end{array}$ & + & $-1+$ & $++{ }^{\mathrm{N}}+{ }^{\mathrm{C}}$ \\
\hline \multicolumn{6}{|l|}{$\operatorname{ER} \beta$} \\
\hline Epithelium & $\begin{array}{c}-{ }^{\mathrm{N}}++ \\
+{ }^{\mathrm{C}}\end{array}$ & $+^{\mathrm{N}}++^{\mathrm{C}}$ & $+{ }^{\mathrm{N}}+++{ }^{\mathrm{C}}$ & $\begin{array}{c}+^{\mathrm{N}}+ \\
+/++ \\
{ }^{\mathrm{C}}\end{array}$ & $\begin{array}{c}-{ }^{N}++ \\
+{ }^{C}\end{array}$ \\
\hline Stroma & - & - & - & - & - \\
\hline Muscle layer & $+{ }^{\mathrm{C}}$ & $++^{\mathrm{N}}+{ }^{\mathrm{C}}$ & + & + & $-{ }^{\mathrm{N}}+{ }^{\mathrm{C}}$ \\
\hline
\end{tabular}

Reactions were classified as strong $(+++)$, moderate $(++)$, low $(+)$ and absent $(-)$. ${ }^{\text {, N }}$ Different staining intensities in the cytoplasm (C) and nucleus (N).

of the epithelial cells of the animals treated with the doses of 1.87, 7.5 and $15 \mathrm{mg} \mathrm{ND} / \mathrm{kg}$, compared to the control group. In addition, these ND-treated groups expressed less ER $\alpha$ nuclear immunostaining compared to the control group (Table 2; Fig. 4A, E, I, M and Q; 5C). Only in the group treated with the highest dose of ND the strong intensity of cytoplasmic ER $\alpha$ immunostaining was maintained in the PR period and there was an increase in nuclear ER $\alpha$ expression, when compared to PT period (Table 2; Fig. 4R). In the stroma of the ampulla the nuclear ER $\alpha$ immunostaining was low (control, 7.5 and $15 \mathrm{mg} \mathrm{ND} / \mathrm{kg}$ groups) or moderate (1.87 and $3.75 \mathrm{mg} \mathrm{ND} / \mathrm{kg}$ groups) after treatment period (Table 2). In the PR period, ER $\alpha$ immunolabelling was reduced in the groups receiving 1.87 and $3.75 \mathrm{mg} \mathrm{ND} / \mathrm{kg}$, and increased in the $15 \mathrm{mg} \mathrm{ND} / \mathrm{kg}$ group, compared to the PT period. The muscle fibers exhibited moderate nuclear ER $\alpha$ expression in animals that received the highest doses (7.5 and $15 \mathrm{mg} \mathrm{ND} / \mathrm{kg}$ ), while in animals of control, 1.87 and $3.75 \mathrm{mg} \mathrm{ND} / \mathrm{kg}$ groups, this expression was strong in the PT period (Table 2; Fig. 4). There was a decrease in the ERa immunolabelling in the muscular layer of the groups treated with 3.75 and $7.5 \mathrm{mg} \mathrm{ND} / \mathrm{kg}$ after a recovery period.

After treatments, the epithelium showed strong staining intensity level for the cytoplasmic ER $\beta$ and absence of nuclear expression in all experimental groups (Table 2; Fig. 4C, G, K, O and S; 5D). In the PR period, only the dose of $1.87 \mathrm{mg} \mathrm{ND} / \mathrm{kg}$ was able to reduce the cytoplasmic ER $\beta$ immunostaining. No ER $\beta$ immunostaining was observed in the stromal cells regarding the PT and PR periods (Table 2; Figs. Fig. 4 and Fig. 55D). The cytoplasm of the muscle cells exhibited ER $\beta$ immunostaining in the control and ND-treated groups, ranging from low to moderate intensity after treatment period (Table 2). In the PR period, there was moderate staining intensity for the nuclear ER $\beta$ in lowest dose $(1.87 \mathrm{mg} \mathrm{ND} / \mathrm{kg})$, whereas in the highest dose $(15 \mathrm{mg} \mathrm{ND} / \mathrm{kg})$ this expression was absent. The cytoplasmic ER $\beta$ immunostaining was low in the muscle layer of all experimental groups.

\section{Discussion}

Several studies have focused attention to the effects of AAS on the ovaries and uterus, but little is known about the effects of these drugs on the fallopian tube. Herein, we evaluated the effects of different doses of ND on the ampulla of the fallopian tube, especially involving the expression of androgen receptor (AR), and estrogen receptors (ER $\alpha$ and ER $\beta$ subunits) after treatment and recovery periods.

In this study, all doses of ND promoted estrous acyclicity in females and the histology of ampullary portion of the fallopian tube did not present a dose-response effect. In addition, sex steroid receptors (AR, $\mathrm{ER} \alpha$ and ER $\beta$ ) were differentially expressed in the tissues, depending on the dose and period of evaluation (PT and PR).

The deleterious effects promoted by different doses of ND on estrous cycle and ovarian and uterine tissues, after treatment and recovery periods, were previously documented (Simão et al., 2015; Simão et al., 2016; Belardin et al., 2014). In these studies, ND was reported to induce dose- and time-dependent effect on the estrous cycle, folliculogenesis, luteogenesis and histological structure of the uterine layers, in addition to have a role on the suppression of fertile capacity of rats (Belardin et al., 2014). However, the results of the present study suggest that the fallopian tube responds in a dose-independent manner to the ND effects and no profound histopathological change was found when the dose levels are increased.

In several mammalian species, structural and functional changes occur in the tubal epithelium throughout the phases of the estrous cycle, in response to estrogen $\left(\mathrm{E}_{2}\right)$ and progesterone $\left(\mathrm{P}_{4}\right)$ levels. In addition, there is variation in the rate of ciliated and secretory cells and the expression of AR and ERs is cell- and - region dependent (Ayen et al., 2012; Özen et al., 2010; Horne et al., 2009; Okada et al., 2003). In our study, we observed that ND-treated animals, which exhibited diestrus throughout the treatment and recovery periods, presented a particular pattern of response in the genital duct, for each dose evaluated.

Surprisingly, the lower dose of ND $(1.87 \mathrm{mg} / \mathrm{kg})$ induced a number of histomorphometric changes in the ampulla after the treatment period. These were characterized by irregularities in the longitudinal folds of the mucosal layer, increase of the luminal area, morphological atypia of the ciliated cells, and reduction in muscle layer thickness. There was a partial recovery of the tissue after the period of interruption of steroid treatment. However, the mucosa layer kept the irregular folds and the ciliated cells with a pale appearance and reduced height. This condition may result in failures to the transport of the gametes and zygote, leading to decreased fertility rate (Akison et al., 2014).

At the dose of $3.75 \mathrm{mg} \mathrm{ND} / \mathrm{kg}$, few histomorphometric changes were observed in fallopian tube after the PT period, as well as in doses of 7.5 and $15 \mathrm{mg} \mathrm{ND} / \mathrm{kg}$. In these androgenized groups the most prominent histological feature was vasodilation in the interstitial tissue of the muscular layer. The same result was previously reported in the ovarian medulla (Simão et al., 2015), considering both PT and PR periods. In another study (Souza et al., 2017), a mixture of testosterone esters administered at a dose of $7.5 \mathrm{mg} / \mathrm{kg}$ for 15 days promoted vascular congestion, vasodilation, and interstitial hemorrhage in the testes of 


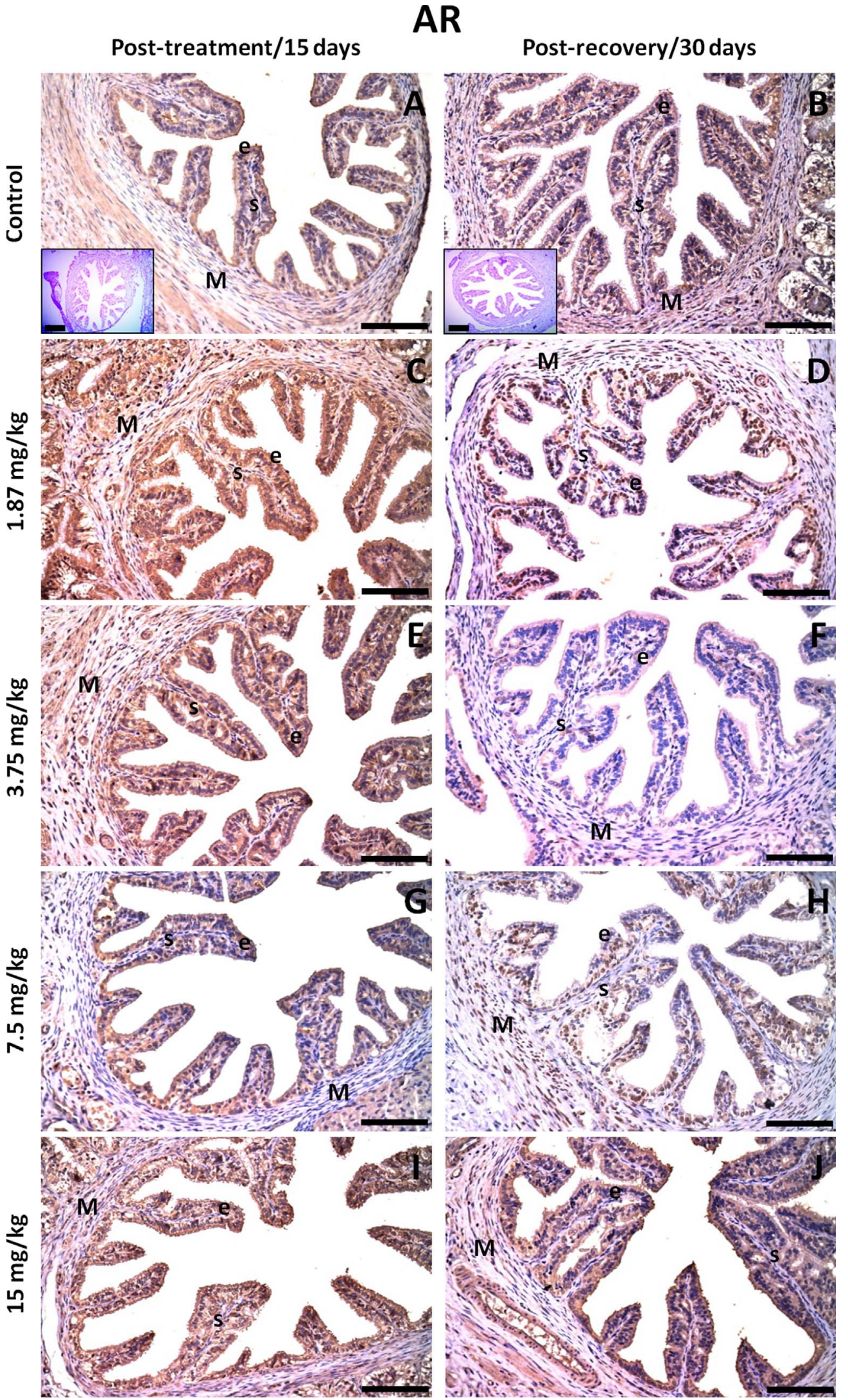

Fig. 3. Immunostaining for $A R$ in the ampulla of the fallopian tube in rats of control group (A, B) and ND-treated groups at doses of $1.87 \mathrm{mg} / \mathrm{kg}$ (C, D), $3.75 \mathrm{mg} / \mathrm{kg}$ (E, F), $7.5 \mathrm{mg} / \mathrm{kg}$ (G, H) and $15 \mathrm{mg} / \mathrm{kg}$ (I, J), after treatment and recovery periods. Moderate to strong AR immunostaining was detected in the cytoplasm of epithelial cells in the ND-treated groups in the PT period. No AR immunostaining was observed in the stroma. Negative control demonstrated no reactivity (highlighted in 3A and 3B; bar: $200 \mu \mathrm{m}$ ). $\mathrm{e}=$ epithelium; $\mathrm{s}=$ stroma; $\mathrm{M}=$ muscle layer. Bars: $100 \mu \mathrm{m}$ (A-J). rats submitted to a post-treatment recovery period. Studies reported that testosterone or its metabolite dihydrotestosterone (DHT) induces direct vasodilation independently of the nuclear AR, which is mediated via modulation of membrane ion channels (Jones et al., 2004; Littleton-
Kearney and Hurn, 2004). The high levels of testosterone and DHT circulating in the body of females receiving doses of 3.75, 7.5 and $15 \mathrm{mg} \mathrm{ND} / \mathrm{kg}$ (Simão et al., 2016) confirmed the action of androgen as vasodilator. The effects of AAS (Sader et al., 2001) or mammalian 


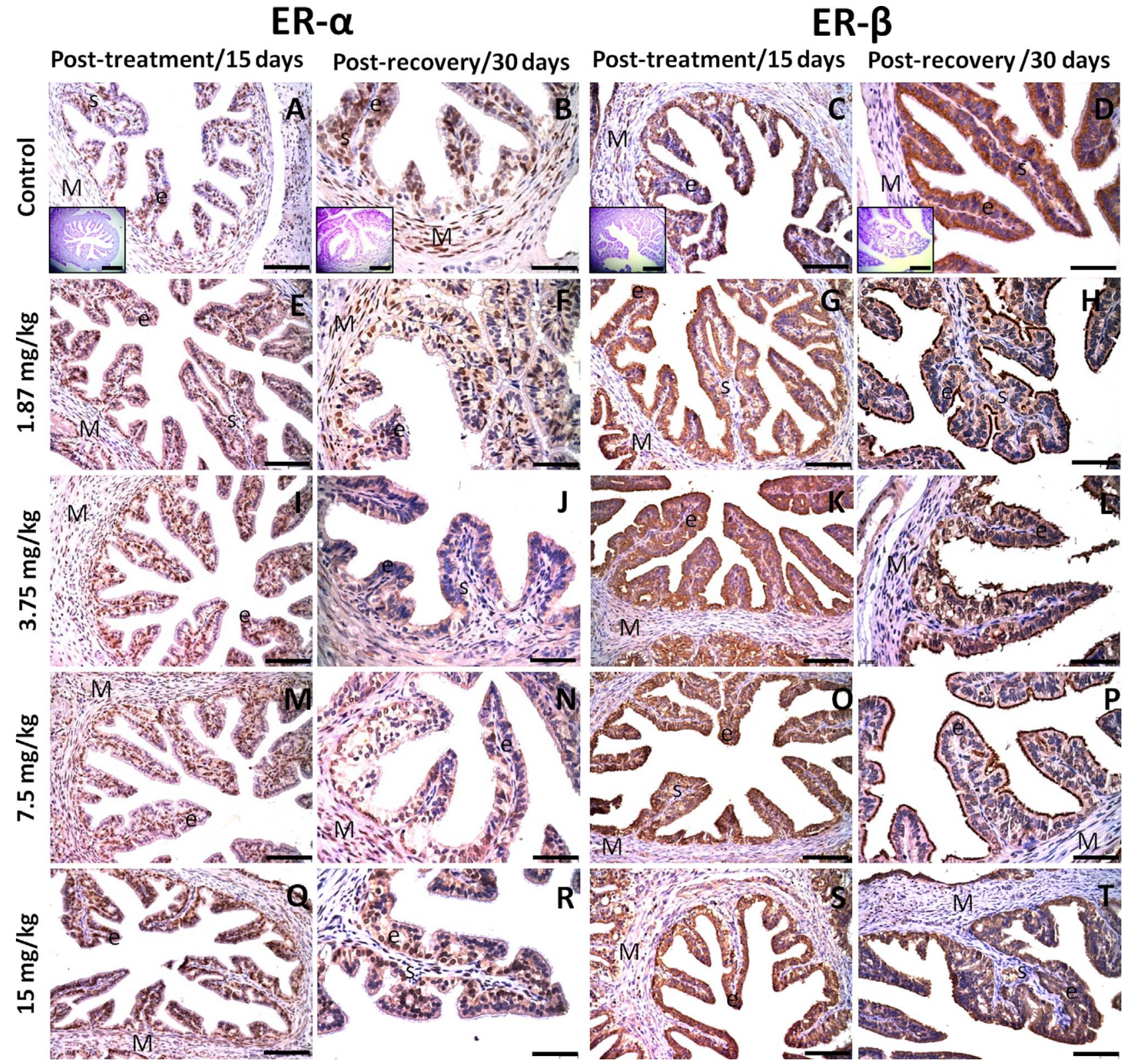

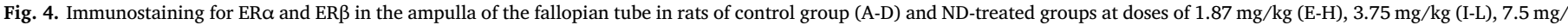

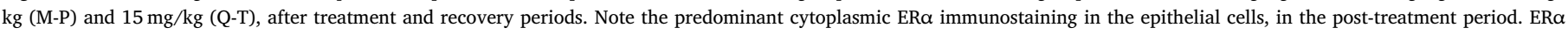

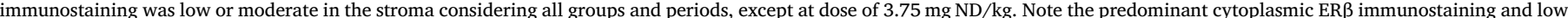

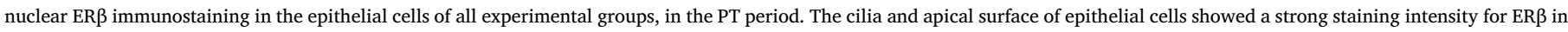

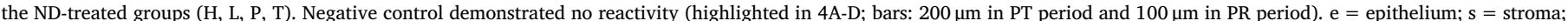
$\mathrm{M}=$ muscle layer. Bars: $100 \mu \mathrm{m}$ (A, C, E, G, I, K, M, O, Q, S); $50 \mu \mathrm{m}$ (B, D, F, H, J, L, N, P, R, T).

androgen (Littleton-Kearney and Hurn, 2004) on vascular properties are complex and depend on the dose, exposure time, type of androgen, and others. Our study demonstrated that vasodilation in the fallopian tube creates an increase in circulating blood flow due to reduced vascular resistance and, as a consequence, there may be rupture of the wall and local hemorrhage.

It is reported that the luteal phase shows lower ciliated cells than the proliferative phase in women, sometimes with rupture and extrusion of the cytoplasm into the lumen (Sokol, 2011). In addition, the heights of secretory and ciliated cells decrease, and there is a partial deciliation (Verhage et al., 1979). According to Patek et al. (1973), the treatment of women with synthetic androgen promotes a decrease in the number of ciliated cells of the ampullary region. In the present study, the ciliated cells were not quantified but it was observed that there was a reduction in the cellular height only in the group that received the lowest dose $(1.87 \mathrm{mg} \mathrm{ND} / \mathrm{kg})$, considering that all NDtreated groups remained in the luteal phase during PT and PR periods. The data suggest that the ciliated cells, a large cell population of the epithelium, respond to the ND during the luteal phase in a dose-dependent level.

The expression and regulation of sex steroid receptors in the fallopian tube of rodents are poorly explored (Shao et al., 2006; Pelletier et al., 2000). According to Okada et al. (2003), this is probably due to its coiled complex structure and composition in four different regions.

Androgens exert their effects after binding to AR. It is well-known that androgens have a key role in ovarian physiological events such as, follicular growth and maturation, atresia and luteinization (Simão et al., 2016; Walters et al., 2008; Drummond et al., 2002). In the fallopian tube, AR and androgens are thought to exert a direct influence on the functions of the organ (Pelletier et al., 2000); however, the 


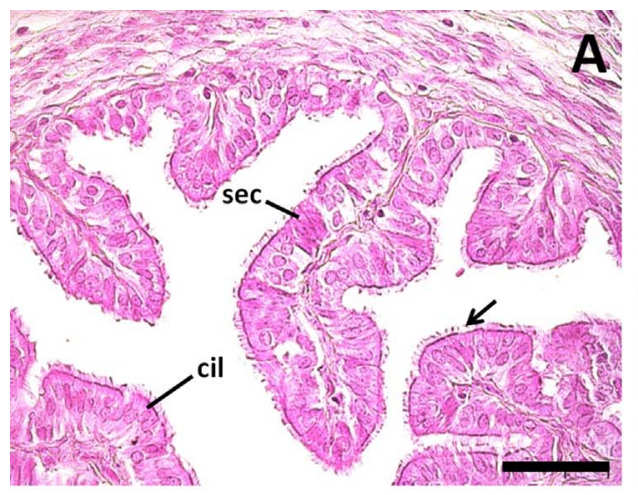

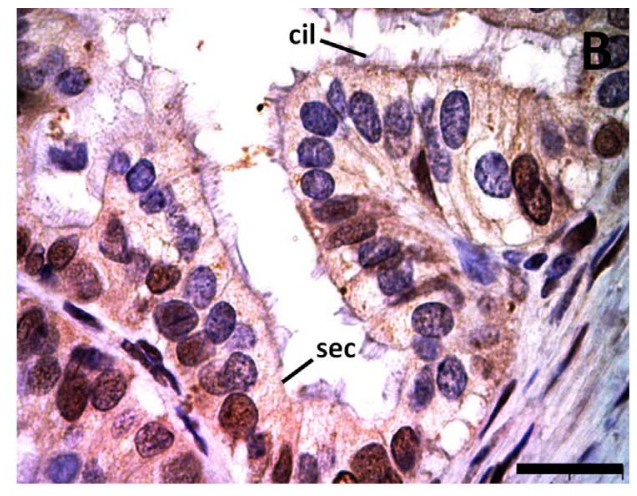

Fig. 5. Photomicrographs of the mucosal folds showing the ciliated (cil) and secretory (sec) epithelial cells. Panel A shows the morphology of the cells and cilia (arrow) in animals treated with $1.87 \mathrm{mg} \mathrm{ND} / \mathrm{kg}$ (H\&E). Panel B shows the cytoplasmic and nuclear AR immunostaining in the ciliated and secretory cells of animals treated with $3.75 \mathrm{mg} \mathrm{ND} / \mathrm{kg}$. Panel C shows the ER $\mathrm{im}$ munostaining in the epithelial cells of animals treated with $7.5 \mathrm{mg} \mathrm{ND} / \mathrm{kg}$. Panel D shows the ER $\beta$ immunostaining in the epithelial cells of animals treated with $15 \mathrm{mg} \mathrm{ND} / \mathrm{kg}$. Bars: $50 \mu \mathrm{m}$ (A, C, D); $20 \mu \mathrm{m}$ (B).
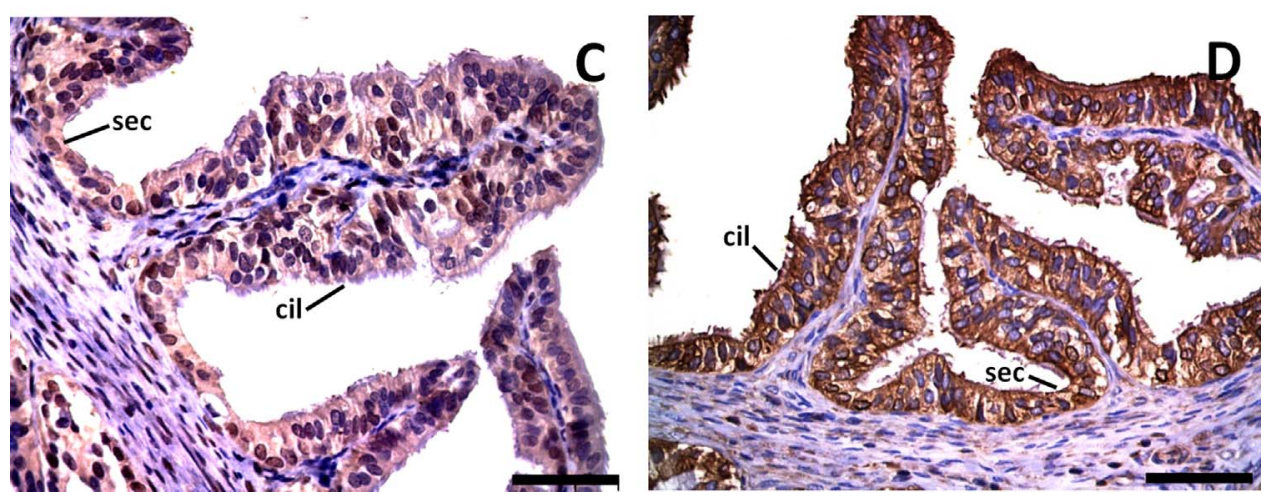

action of androgens on fallopian tube still needs more investigation.

Under normal conditions, AR is located in the nucleus of epithelial cells, stromal and muscle cells of the fallopian tube of rats in diestrus (Pelletier et al., 2000). It is reported that the epithelial cells of ampulla exhibit low immunostaining for nuclear AR (Okada et al., 2003). Shao et al. (2006) showed that in a model of superovulated mouse, the AR immunoreactivity was predominantly detected in the cytoplasm of tubal epithelial cells, whereas nuclear AR localization was absent in the presence of DHT. In the present study, the immunostaining of AR was detected mainly in the cytoplasm of epithelial cells in the androgenized groups, which presented strong AR reaction. After a recovery period, the cytoplasmic AR levels were reduced in the epithelial cells, except for the group that received the highest dose of ND. Then, the administration of exogenous androgen may interfere with the AR expression in epithelium of the fallopian tube due to hyperandrogenic environment, as previously described in ovarian tissue (Simão et al., 2016). In fallopian tube of superovulated mouse, the estrogen may contribute to regulate and activate $\mathrm{AR}$ protein synthesis, but the dynamics of $\mathrm{AR}$ expression still needs to be fully exploited (Shao et al., 2006).

Okada et al. (2003) described that the stromal and muscle cells of the rat ampulla showed low to moderate AR immunoreaction in diestrus. In this study, the experimental groups exhibited muscle cells with staining intensity ranging from low to moderate. However, we found absence of AR immunostaining in stromal cells in all experimental groups, in PT and PR periods. These functional differences can be attributed to different animal model, treatment schedule, and expression pattern of the receptor.

Maintenance of morphological and functional characteristics is estrogen-dependent in the fallopian tube (Bylander, 2014). The ERmediated $\mathrm{E}_{2}$ activity is also implicated in the development and progression of numerous human diseases (Deroo and Korach, 2006). Several studies have shown the association between deciliation of the fallopian tube epithelium and ectopic pregnancy in women (Sharma and Biligi, 2015; Shao et al., 2012). In this pathological condition, expression of sex steroid receptors would be altered in fallopian tube (Horne et al., 2009).

Both ER $\alpha$ and ER $\beta$ isoforms can be associated to the cell membrane, cytoplasm and nucleus of the epithelial cells in rat ampulla (Orihuela et al., 2009). However, ER $\alpha$ is the predominant ER subtype in the fallopian tube of rats (Shao et al., 2007). The cell type-specific localization and ER subtypes in the fallopian tube vary among the species (Shao et al., 2012). In women, ER is expressed by epithelial cells of the ampulla, having an increase in the luteal phase (Amso et al., 1994). In rodents, intense ER $\alpha$ immunostaining is expected for all epithelial cells during the stages of estrous cycle (Okada et al., 2003).

In this study, we observed a variation in nuclear and cytoplasmic ER $\alpha$ immunostaining in the epithelial cells, after PT and PR periods. ERa expression was observed mainly in the cytoplasm of epithelial cells of ND-treated animals, except for $3.75 \mathrm{mg} \mathrm{ND} / \mathrm{kg}$, while nuclear ER $\alpha$ expression was strongly detected in the control group. During diestrus stage, a strong nuclear ER $\alpha$ immunoreaction is observed in the epithelia of ampulla (Okada et al., 2003). This result was only verified in the control animals in diestrus, but the treatment with ND led to increased cytoplasmic ER $\alpha$ expression. Interestingly, high serum levels of E2 were observed only in the groups that received the highest doses of the steroid (Simão et al., 2016), but the expression of cytoplasmic ERa was similar to the group that received the lowest dose. The ER $\alpha$ expression ranged after a recovery period between the experimental groups, being maintained higher at the dose of $15 \mathrm{mg} \mathrm{ND} / \mathrm{kg}$. The presence of ER $\alpha$ in the stromal and smooth muscle cells of the ampullary portion of the fallopian tube were dose- and period-dependent according to previous reports (Orihuela et al., 2009; Wang et al., 2000). Only the highest ND dose maintained ER $\alpha$ expression in both periods. This effect can be attributed to the conversion of androgens into estrogens, and the higher $\mathrm{E}_{2}$ synthesis as well (Simão et al., 2016).

According to Okada et al. (2003), ER $\beta$ immunoreactivity was limited to a few nonciliated epithelial cells in the ampulla of rats and no reaction was detected in stromal cells following the diestrus. It has been also reported that only a few muscle cells exhibit low ER $\beta$ expression (Wang et al., 2000). We observed that the stroma did not exhibit ER $\beta$ immunostaining in any group and experimental period. However, the epithelial and smooth muscle cells presented ER $\beta$ expression in both control and ND-treated groups, in the PT and PR periods. This expression was higher in the epithelium than in the muscular layer, and all 
experimental groups presented a strong cytoplasmic ER $\beta$ immunostaining and absence of nuclear ER $\beta$ expression in the epithelial cells, in the PT period. After a recovery period, the ER $\beta$ immunostaining ranged between the experimental groups, but continued with greater expression in cytoplasm of the epithelial cells. Thus, the excessively androgenic environment seems to not disturb the ER $\beta$ expression. The study confirmed that ERa is the main active ER subtype rather than ERß.

In summary, the rat ampulla (especially the epithelial lining and muscle layer) expressed AR, ER $\alpha$ and ER $\beta$ during PT and PR periods. In stromal cells was detected only expression of ERa. Every androgenized group presented a different pattern of response in regard to the expression of sex receptors following PT and PR periods.

\section{Conclusion}

Nandrolone Decanoate promoted histomorphometric and immunohistochemical changes in the ampullary portion of the fallopian tube after treatment and recovery periods in a dose-independent manner.

\section{Conflicts of interest}

None.

\section{Acknowledgment}

This research did not receive any specific grant from funding agencies in the public, commercial, or not-for-profit sectors.

\section{References}

Özen, A., Ergün, E., Kürüm, A., 2010. Histomorphology of the oviduct epithelium in the Angora rabbit. Turk. J. Vet. Anim. 34, 219-226. http://dx.doi.org/10.3906/vet0710-39.

Abrahin, O.S.C., Souza, N.S.F., Sousa, E.C., Moreira, J.K.R., Nascimento, V.C., 2013. Prevalência do uso e conhecimento de esteroides anabolizantes androgênicos por estudantes e professores de educação física que atuam em academias de ginástica. Rev. Bras. Med. Esporte 19, 27-30. http://dx.doi.org/10.1590/S151786922013000100005.

Akison, L.K., Boden, M.J., Kennaway, D.J., Russell, D.L., Robker, R.L., 2014. Progesterone receptor (PGR) dependent regulation of genes in the oviducts of female mice. Physiol. Genom. 46, 583-592. http://dx.doi.org/10.1152/physiolgenomics.00044.2014.

Amso, N.N., Crow, J., Lewin, J., Shaw, R.W., 1994. A comparative morphological and ultrastructural study of endometrial gland and fallopian tube epithelia at different stages of the menstrual cycle and the menopause. Hum. Reprod. 9, 2234-2241.

Arlt, W., 2006. Androgen therapy in women. Eur. J. Endocrinol. 154, 1-11. http://dx.doi. org $/ 10.1530 /$ eje.1.02062.

Ayen, E., Shahrooz, R., Kazemie, S., 2012. Histological and histomorphometrical changes of different regions of oviduct during follicular and luteal phases of estrus cycle in adult Azarbaijan buffalo. Iran. J. Vet. Res. 13, 42-48. http://dx.doi.org/10.22099/ ijvr.2012.19.

Belardin, L.B., Simão, V.A., Leite, G.A.A., Chuffa, L.G.A., Camargo, I.C.C., 2014. Dosedependent effects and reversibility of the injuries caused by nandrolone decanoate in uterine tissue and fertility of rats. Birth Defects Res. Part B - Dev. Reprod. Toxicol. 101, 168-177. http://dx.doi.org/10.1002/bdrb.21104.

Bento-Silva, M.T., De Carvalho E. Martins, M.D.C., Torres-Leal, F.L., Barros, T.L., De Carvalho, I.L.D.N.F., Carvalho Filho, H.A., Almeida, F.R.D.C., 2010. Effects of administering testosterone undecanoate in rats subjected to physical exercise: effects on the estrous cycle, motor behavior and morphology of the liver and kidney. Braz. J. Pharm. Sci. 46, 79-89. http://dx.doi.org/10.1590/S1984-82502010000100009.

Berne, R.M., Levy, M.N., 2000. As glândulas reprodutoras. In: Berne, R.M., Levy, M.N. (Eds.), Fisiologia. Guanabara Koogan, Rio de Janeiro, pp. 910-956.

Blasberg, M.E., Robinson, S., Henderson, L.P., Clark, A.S., 1998. Inhibition of estrogeninduced sexual receptivity by androgens: role of the androgen receptor. Horm. Behav. 34, 283-293. http://dx.doi.org/10.1006/hbeh.1998.1484.

Bonetti, A., Tirelli, F., Catapano, A., Dazzi, D., Cas, A., Solito, F., Ceda, C., Reverberi, C., Monica, C., Pipitone, S., Elia, G., Spattini, M., Magnati, G., 2008. Side effects of anabolic androgenic steroids abuse. Int. J. Sports Med. 29, 679-687. http://dx.doi. org/10.1055/s-2007-965808.

Bylander, A., Lind, K., Goksör, M., Billig, H., Larsson, D.G.J., 2013. The classical progesterone receptor mediates the rapid reduction of fallopian tube ciliary beat frequency by progesterone. Reprod. Biol. Endocrinol. 11 (33). http://dx.doi.org/10. 1186/1477-7827-11-33.

Bylander, A., 2014. Progesterone's Effect on Gamete Transport in the Fallopian Tube. University of Gothenburg. https://gupea.ub.gu.se/bitstream/2077/36749/1/gupea 2077_36749_1.pdf.

Camargo, I.C.C., Gaspar, A.L.C., Frei, F., Mesquita, S.F.P., 2009. Efeitos dos esteroides anabólicos androgênicos sobre o útero e parâmetros reprodutivos de ratas adultas. Rev. Bras. Ginecol. e Obs. 31, 453-460. http://dx.doi.org/10.1590/S010072032009000900006.

Camargo, I.C.C., Leite, G.A.A., Pinto, T., Ribeiro-Paes, J.T., 2014. Histopathologycal findings in the ovaries and uterus of albino female rats promoted by co-administration of synthetic steroids and nicotine. Exp. Toxicol. Pathol. 66, 195-202. http://dx. doi.org/10.1016/j.etp.2014.01.005.

Cannavo, S., Curtò, L., Cannavò, S., Curtò, L., Trimarchi, F., 2001. Exercise-related female reproductive dysfunction. J. Endocrinol. Invest. 823-832. http://dx.doi.org/10. 1007/BF03343935.

Chuffa, L.G.A., Souza, R.B., Frei, F., Mesquita, S.D.F.P., Camargo, I.C.C., 2011. Nandrolone decanoate and physical effort: histological and morphometrical assessment in adult rat uterus. Anat. Rec. 294, 335-341. http://dx.doi.org/10.1002/ar. 21314.

Deroo, B.J., Korach, K.S., 2006. Estrogen receptors and human disease. J. Clin. Invest 116, 561-570. http://dx.doi.org/10.1172/JCI27987.

Donnez, J., Casanas-Roux, F., Caprasse, J., Ferin, J., Thomas, K., 1985. Cyclic changes in ciliation, cell height, and mitotic activity in human tubal epithelium during reproductive life. Fertil. Steril. 43, 554-559. http://dx.doi.org/10.1016/S00150282(16)48496-7.

Drummond, A.E., Britt, K.L., Dyson, M., Jones, M.E., Kerr, J.B., O'Donnell, L., Simpson, E.R., Findlay, J.K., 2002. Ovarian steroid receptors and their role in ovarian function. Mol. Cell. Endocrinol. 191, 27-33. http://dx.doi.org/10.1016/S0303-7207(02) 00052-7.

Evans, N.A., 2004. Current conceptions in anabolic-androgenic steroids. Am. J. Sports Med. 32, 534-542. http://dx.doi.org/10.1177/0363546503262202.

Frizon, F., Macedo, S.M.D., Yonamine, M., 2005. Uso de esteróides andrógenos anabólicos por praticantes de atividade física das principais academias de Erechim e Passo Fundo/RS. Rev. Cienc. Farm. Básica Apl. 26, 227-232.

Gerez, J.R., Frei, F., Camargo, I.C.C., 2005. Histological assessment of ovaries and uterus of rats subjected to nandrolone decanoate treatment. Contraception 72, 77-80. http://dx.doi.org/10.1016/j.contraception.2005.02.001.

Goldberg, J.M., Friedman, C.I., 1995. Effect of hormonal manipulation on human fallopian tubal epithelium in vitro. J. Assist. Reprod. Genet. 12, 132-135. http://dx.doi. org/10.1007/BF02211382.

Goldman, J.M., Murr, A.S., Cooper, R.L., 2007. The rodent estrous cycle: characterization of vaginal cytology and its utility in toxicological studies. Birth Defects Res. B Dev. Reprod. Toxicol. 80, 84-97. http://dx.doi.org/10.1002/bdrb.20106.

Hoffman, J.R., Ratamess, N.A., 2006. Medical issues associated with anabolic steroid use: are they exaggerated? J. Sports Sci. Med. 5, 182-193.

Horne, A.W., King, A.E., Shaw, E., McDonald, S.E., Williams, A.R.W., Saunders, P.T., Critchley, H.O.D., 2009. Attenuated sex steroid receptor expression in Fallopian tube of women with ectopic pregnancy. J. Clin. Endocrinol. Metab. 94, 5146-5154. http:// dx.doi.org/10.1210/jc.2009-1476.

Iriart, J.A.B., Chaves, J.C., De Orleans, R.G., 2009. Culto ao corpo e uso de anabolizantes entre praticantes de musculação. Cad. Saúde Públ. 25, 773-782. http://dx.doi.org/ 10.1590/S0102-311x2009000400008.

Jones, R.D., Jones, T.H., Channer, K.S., 2004. The influence of testosterone upon vascular reactivity. Eur. J. Endocrinol. 151, 29-37.

Kam, P.C.A., Yarrow, M., 2005. Anabolic steroid abuse: physiological and anaesthetic considerations. Anaesthesia 60, 685-692. http://dx.doi.org/10.1111/j.1365-2044. 2005.04218.x.

Kicman, A.T., 2008. Pharmacology of anabolic steroids. Br. J. Pharmacol. 154, 502-521. http://dx.doi.org/10.1038/bjp.2008.165.

Littleton-Kearney, M., Hurn, P.D., 2004. Testosterone as a modulator of vascular behavior. Biol. Res. Nurs. 5, 276-285. http://dx.doi.org/10.1177/1099800403262927.

Lyons, R.A., Saridogan, E., Djahanbakhch, O., 2006. The effect of ovarian follicular fluid and peritoneal fluid on Fallopian tube ciliary beat frequency. Hum. Reprod. 21, 52-56. http://dx.doi.org/10.1093/humrep/dei306.

Mahmood, T., Saridogan, E., Smutna, S., Habib, A.M., Djahanbakhch, O., 1998. The effect of ovarian steroids on epithelial ciliary beat frequency in the human Fallopian tube. Hum. Reprod. 13, 2991-2994.

Maravelias, C., Dona, A., Stefanidou, M., Spiliopoulou, C., 2005. Adverse effects of anabolic steroids in athletes - a constant threat. Toxicol. Lett. 158, 167-175. http://dx. doi.org/10.1016/j.toxlet.2005.06.005.

Mobini Far, H.R., Ågren, G., Lindqvist, A.S., Marmendal, M., Fahlke, C., Thiblin, I., 2007. Administration of the anabolic androgenic steroid nandrolone decanoate to female rats causes alterations in the morphology of their uterus and a reduction in reproductive capacity. Eur. J. Obstet. Gynecol. Reprod. Biol. 131, 189-197. http://dx. doi.org/10.1016/j.ejogrb.2006.07.037.

Okada, A., Ohta, Y., Inoue, S., Hiroi, H., Muramatsu, M., Iguchi, T., 2003. Expression of estrogen, progesterone and androgen receptors in the oviduct of developing, cycling and pre-implantation rats. J. Mol. Endocrinol. 30, 301-315. http://dx.doi.org/10. 1677/jme.0.0300301.

Orihuela, P.A., Zuñiga, L.M., Rios, M., Parada-Bustamande, A., Sierralta, W.D., Velásquez, L.A., Croxatto, H.B., 2009. Reprod. Biol. Endocrinol. 7, 139. http://dx.doi.org/10. 1186/I477-7827-7-139.

Patek, E., Nilsson, L., Johannisson, E., 1972. Scanning electron microscopic study of the human fallopian tube. Report I. The proliferative and secretory stages. Fertil. Steril. 23, 459-465. http://dx.doi.org/10.1016/S0015-0282(16)39070-7.

Patek, E., Nilsson, L., Hellema, M., 1973. Scanning electron microscopic study of the human fallopian tube. Report IV. At term gestation and in the puerperium. The effect of a synthetic progestin on the postmenopausal tube. Fertil. Steril. 24, 832-843. http://dx.doi.org/10.1016/S0015-0282(16)40029-4. 
Pelletier, G., Labrie, C., Labrie, F., 2000. Localization of oestrogen receptor $\alpha$, oestrogen receptor $\beta$ and androgen receptors in the rat reproductive organs. J. Endocrinol. 165, 359-370.

Rocha, M., Aguiar, F., Ramos, H., 2014. O uso de esteroides androgénicos anabolizantes e outros suplementos ergogénicos - uma epidemia silenciosa. Rev. Port. Endocrinol. Diabetes Metab. 9, 98-105. http://dx.doi.org/10.1016/j.rpedm.2014.09.002.

Sader, M.A., Griffiths, K.A., McCredie, R.J., Handelsman, D.J., Celermajer, D.S., 2001. Androgenic anabolic steroids and arterial structure and function in male bodybuilders. JACC 37, 224-230. http://dx.doi.org/10.1016/S0735-1097(00)01083-4.

Shahidi, N.T., 2001. A review of the chemistry, biological action, and clinical applications of anabolic-androgenic steroids. Clin. Ther. 23, 1355-1390. http://dx.doi.org/10. 1016/S0149-2918(01)80114-4.

Shao, R., Ljungström, K., Weijdegård, B., Egecioglu, E., Fernandez-Rodriguez, J., Zangh, F.P., Thurin-Kjellberg, A., Bergh, C., Billig, H., 2006. Estrogen-induced upregulation of AR expression and enhancement of AR nuclear translocation in mouse fallopian tubes in vivo. Am. J. Physiol. Endocrinol. Metab. 292, E604-614. http://dx.doi.org/ 10.1152/ajpendo.00350.2006.

Shao, R., Weijdegård, B., Fernandez-Rodriguez, J., Egecioglu, E., Zhu, C., Andersson, N., Thurin-Kjellberg, A., Bergh, C., Billig, H., 2007. Ciliated epithelial-specific and regional-specific expression and regulation of the estrogen receptor-beta2 in the fallopian tubes of immature rats: a possible mechanism for estrogen-mediated transport process in vivo. Am. J. Physiol. Endocrinol. Metab. 293, E147-E158. http://dx.doi. org/10.1152/ajpendo.00101.2007.

Shao, R., Feng, Y., Zou, S., Weijdegård, B., Wu, G., Brännström, M., Billig, H., 2012. The role of estrogen in the pathophysiology of tubal ectopic pregnancy. Am. J. Transl. Res. 4, 269-278.
Sharma, R., Biligi, D.S., 2015. A study of histopathological changes in fallopian tubes in ectopic pregnancy. Int. J. Curr. Res. Rev. 7, 6-10.

Simão, V.A., Belardin, L.B., Araújo Leite, G.A., de A. Chuffa, L.G., Camargo, I.C.C., 2015 Effects of different doses of nandrolone decanoate on estrous cycle and ovarian tissue of rats after treatment and recovery periods. Int. J. Exp. Pathol. 96, 338-349. http:// dx.doi.org/10.1111/iep.12144.

Simão, V.A., Chuffa, L.G.A., Camargo, I.C.C., 2016. Ovarian sex steroid receptors and sex hormones in androgenized rats. Reproduction 152, 545-559. http://dx.doi.org/10. 1530/REP-16-0233.

Sokol, E.R., 2011. Clinical anatomy of the uterus, fallopian tubes and ovaries. Glob. Libr. Women's Med 103843/GLOWM.10001. http://www.glowm.com/section_view/ item/1.

Souza, B.R., Mathias, L.S., Souza, T.I.M., Camargo, I.C.C., 2017. Histopathological and morphometric evaluation in the testis and epididymis of adult rats submitted to a recovery period after treatment with anabolic steroid, alcohol, and/or nicotine. J. Interdiscipl. Histopathol. 5, 92-98. http://dx.doi.org/10.5455/jihp. 20170124093401.

Verhage, H.G., Bareither, M.L., Jaffe, R.C., Akbar, M., 1979. Cyclic changes in ciliation, secretion and cell height of the oviductal epithelium in women. Am. J. Anat. 156, 505-521. http://dx.doi.org/10.1002/aja.1001560405.

Walters, K.A., Allan, C.M., Handelsman, D.J., 2008. Androgen actions and the ovary. Biol. Reprod. 78, 380-389. http://dx.doi.org/10.1095/biolreprod.107.064089.

Wang, H., Eriksson, H., Sahlin, L., 2000. Estrogen receptors $\alpha$ and $\beta$ in the female reproductive tract of the rat during the estrous cycle. Biol. Reprod. 63, 1331-1340. http://dx.doi.org/10.1095/biolreprod63.5.1331. 